\title{
Letters
}

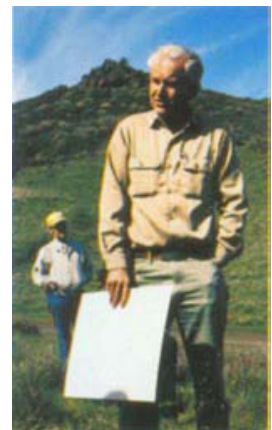

Al Murphy, first superintendent of the Hopland Research and Extension Center, died in December.

\section{Hopland special issue}

My father, Alfred Murphy, was superintendent of the Hopland Field Station for more than 30 years. We were all very excited about the special issue (November-December 2001). I grew up on the Field Station and have very fond memories of those years. We plan to share the issue with family and friends. I even have a copy of your July 1976 special issue on the station's 25 years of research.

You may not be aware that my father passed away on Dec. 22 in Cartersville, Georgia. We both missed California very much and Hopland even more.

Peg (Murphy) Baron

Cartersville, Georgia

The issue devoted to the UC Hopland Research and Extension Center is excellent, with much good information. I've worked closely over the years with researchers at UC Davis/Hopland and value the contributions they have made to sheep research.

David L. Thomas

Professor of Sheep Genetics and Management University of Wisconsin, Madison

\section{BIOS cost data}

I really enjoyed the recent article about almond management ("BIOS and conventional orchard management compared," September-October 2001). It seemed to me to be solid evidence for the viability of less insecticide use. I wonder if you have cost data that correspond with these treatment years, such as what's the difference in investment in insecticides versus not doing so. The last paragraph was a little unsettling: "Many growers will not stop applying the broad- spectrum insecticides," "until reliable predictive techniques are identified." If this study doesn't persuade people, perhaps information on the cost differential will provide a needed "assist."

Dennis Pendleton

Dean, UC Davis Extension

Author Walt Bentley responds: No one has yet performed a comprehensive economic analysis. With fewer input costs, BIOS methods would appear to be more profitable. However, that doesn't take into account bonuses paid by processors for damage of $2 \%$ or less (up to 10 cents per pound). Many growers may use insecticide sprays to achieve this goal.

\section{Agricultural easements cover}

I am very concerned about the cover of your magazine (January-February 2002). The pictures were spliced together to depict homes encroaching on virgin land. You have planted the seed of urbanization encroaching on this land.

\section{Bowerman}

Anza, California

Editor's response: We juxtaposed two images on the cover, identifying them in the caption and demarcating them in the composite image itself (with a light green line where the houses "broke" and the green trees began). We made a composite of these images intentionally to dramatize the two forces at work in California, the movement to preserve farmland and natural lands, and the movement to develop those lands. Our intent was to provide an arresting and thoughtprovoking image that would motivate readers to examine the contents and draw their own conclusions.

\section{Science briefs}

\section{Africanized bees discovered in central San Joaquin Valley}

UC Davis entomologist Dave Nielsen has identified two Africanized bees in Tulare County, the first time the highly defensive bees have been found in the central San Joaquin Valley.

Last fall, Nielsen sampled about 150 bees from 30 different sites between Atwater to the north and Bakersfield (Oildale) to the south, in the region of Highway 99 and the Sierra foothills. The two Africanized bees were identified near the towns of Lindsay and Posey, using PCRamplified mitochondrial DNA markers.

"There are a great number of bee colonies in the area," Nielsen says. "If you don't find Africanized bees, it doesn't mean they're not there. Therefore, our results are a conservative estimate of their range expansion."

"They're moving up the San Joaquin Valley," says Scott Kinnee of the California Department of Food and Agriculture's (CDFA) Plant Pest Diagnostic Center. "They're probably even further up than that, but the sampling hasn't been done yet."

Bees from South Africa were released in Brazil in 1956, and have been slowly making their way northward. California's first Africanized honeybees were discovered in Blythe (Riverside County) in October 1994. More than 51,000 square miles of the state are now considered colonized.

Africanized and European honeybees have the same appearance and venom, and each bee stings only once. But Africanized honeybees guard a larger area around their hives, respond faster and in larger numbers, and can chase their foes for as much as a quarter-mile.

Their impact on agriculture, which relies on bees for pollinization, has been minimal. "Agriculture generally relies on commercial hives from out of state," Kinnee says. Beekeepers continue to 


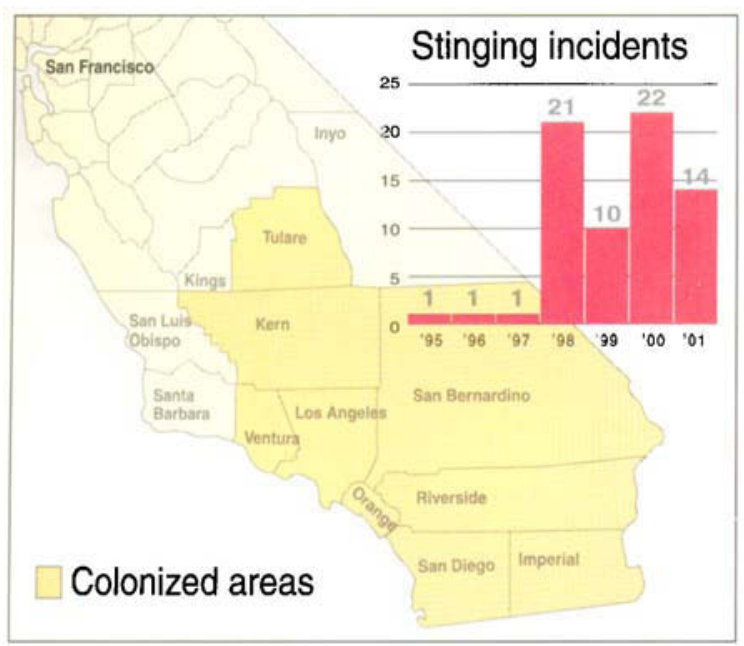

Since entering California in the mid-1990s, Africanized bees have slowly made their way northward; the latest confirmed finds were in Tulare County (map). At the same time, reports of multiple stinging incidents (inset) by Africanized bees have increased. Source: California Department of Food and Agriculture.

tend their hives, but must be vigilant and replace the queens in aggressive colonies.

However, Africanized honeybees tend to colonize niche spaces in urban areas, such as abandoned structures and vehicles, fences and empty boxes. "As the range of the bee has grown, there has been increased contact with areas populated by humans and domestic animals," Kinnee says. "This has resulted in a rising number of stinging incidents."

Seventy incidents of multiple stinging were reported to CDFA between December 1995 and late January 2002, when a 5th-grade boy in West Covina (Los Angeles County) was stung after throwing rocks at a hive.

For more information, go to: www.cdfa.ca.gov/ phpps/pdep/ahb_profile.htm

\section{New wildlife center cleans oiled birds}

The new San Francisco Bay Oiled Wildlife Care and Education Center, which opened its doors in February 2001, faced its first crisis 11 months later when hundreds of oiled birds started turning up in Pacific waters from Point Reyes to Monterey.

As of February, the spill had incapacitated or killed more than 1,500 seabirds, mostly common murres. Hundreds were taken to the center for treatment and rehabilitation; more than 200 birds were released back into the wild.

Located in Cordelia, the facility is one of nine regional centers in the statewide Oiled Wildlife Care Network, which is managed by the UC Davis Wildlife Health Center, a unit of the UC Davis School of Veterinary Medicine. The California Department of Fish and Game (DFG) funds the network with monies assessed on the oil industry.

"Unlike any previous spill in the Bay Area, we now have a facility in place, designed specifically to care for up to 1,000 oiled birds," says Michael Ziccardi, one of four UC Davis wildlife veterinarians who manage animal care for the network. "From the first day, birds have received care as soon as they were found, instead of having to wait, sick and cold, while we put together a rescue center."

When a bird arrives at the 12,000-square-foot, $\$ 2.7$ million center, it is evaluated, treated, washed and rehabilitated by professional staff, with the assistance of volunteers.

The U.S. Coast Guard Marine Safety Office (San Francisco) and the DFG Office of Spill Prevention and Response announced Feb. 8 that the source of the current spill is the SS Jacob Luckenbach, a 468-foot freighter that sank about 17 miles west of the Golden Gate Bridge on July 14, 1953, after a collision.

Oil samples gathered from the ship matched oil found on the feathers of birds and tarballs on the shoreline. Furthermore, oil from the current spill matched samples from similar incidents in 1992, 1997, 1999 and 2001. Altogether, oil from the SS Luckenbach's leaking hull may have killed as many as 10,000 seabirds. Officials are now working on a plan to bring up or seal the freighter.

For more information, go to: www.vetmed. ucdavis.edu/owcn/

\section{- Compiled from U.C. and other news sources}

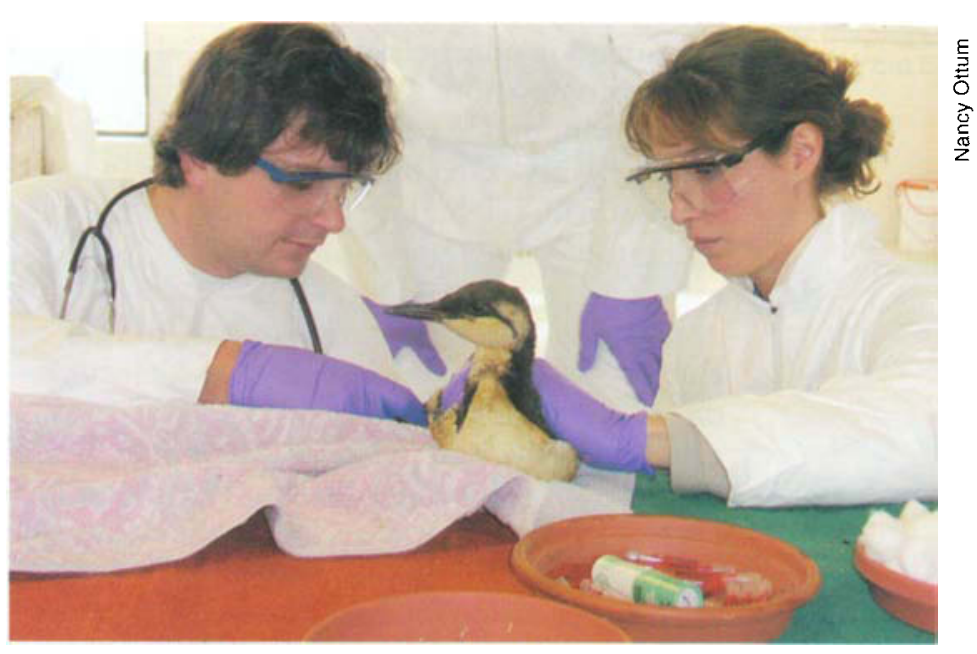

The San Francisco Bay Oiled Wildlife Care and Education Center faced its first crisis when oiled birds began washing up on Bay Area beaches in late November 2001. Above, veterinarians Marty Haulena of the Marine Mammal Center and Christine Kreuder of UC Davis Wildlife Health Center treat a murre. 